\title{
Nutritional Supplement Drink
}

National Cancer Institute

\section{Source}

National Cancer Institute. Nutritional Supplement Drink. NCI Thesaurus. Code C74452.

A calorie-dense nutritional supplement drink containing a variety of vitamins and minerals.

Nutritional supplement drink contains vitamin A, vitamin C, D, E and K, calcium, iron,

thiamin, riboflavin, niacin, folate, vitamin B6, vitamin B12, pantothenic acid, biotin,

phosphorus, iodine, magnesium, zinc, selenium, copper, manganese, chromium,

molybdenum, chloride and choline. In addition, this drink contains protein, fiber and fa,

including omega-3 fatty acids. 